\title{
On-Line Appendix
}

\author{
Reported EFFECTS VS. \\ Revealed-Preference Estimates: Evidence \\ FROM THE PROPENSITY TO SPEND TAX REBATES*
}

\section{American Economic Review: Insights}

\author{
Jonathan A. Parker \\ Nicholas S. Souleles \\ MIT and NBER \\ University of Pennsylvania and NBER
}

*Parker: MIT Sloan School of Management, 77 Massachusetts Avenue, Building E62-642, Cambridge MA 02139-4307; http://japarker.scripts.mit.edu/ ; Souleles: The Wharton School, University of Pennsylvania, 2300 Steinberg Hall - Dietrich Hall, Philadelphia, PA 19104-6367; http://finance.wharton.upenn.edu/ ${ }^{\sim}$ souleles/. 


\section{A Appendix}

\section{A.1 Additional details on the economic stimulus payments of 2008}

Each stimulus payment consisted of a basic payment of $\$ 600$ for individual filers or $\$ 1,200$ for joint filers, increased by $\$ 300$ per child that qualified for the child tax credit. To be eligible, a taxpayer had to have either positive income tax liability or at least $\$ 3,000$ in qualified earnings. For households with low earnings, the payment amount was reduced but not below $\$ 300$ for individuals or $\$ 600$ for joint filers. For households with high earnings, the payment amount was reduced by five percent of the amount by which adjusted gross income exceeded a threshold of $\$ 75,000$ of for individuals and $\$ 150,000$ for joint filers. All income and dependent information was based on tax returns for year 2007. If subsequently a household's tax year 2008 data implied a larger payment, the household could claim the difference on its 2008 return filed in 2009. However, if the 2008 data implied a smaller payment, the household did not have to return the difference.

Within each of two groups, the timing of the payment was determined by the last two digits of the recipient's Social Security number, digits which are effectively randomly assigned. ${ }^{1}$ For recipients that had provided the IRS with their personal bank routing number (i.e., for direct deposit of tax refunds), the stimulus payments were disbursed electronically over three one-week periods ranging from late April to mid-May. ${ }^{2}$ The IRS mailed a statement to these recipients informing them about the deposit a couple of business days before the electronic transfer of funds. An example of this letter is contained later in Appendix A.10. For recipients that did not provide a personal bank routing number, the payments were mailed (using paper checks) in one of nine one-week periods ranging from mid-May to mid-July. For these recipients, the IRS sent a notification letter one week before the check was mailed. Table A.1 shows the weekly disbursement schedule in terms of the latest date by which the payments are supposed to have been received by different households.

For a number of reasons - primarily filing a late tax return - a small share of payments were distributed later than the schedule dictated. For example, taxpayers who filed their tax returns after April 15 and before October 15 received payments either in their allotted time based on their SSN, or as soon as possible after this date (about two weeks after they would receive a refund). We are interested in comparing cleanly-identified causal estimates to reported causal estimates. We therefore exclude households with late payments from

\footnotetext{
${ }^{1}$ The last four digits of a Social Security number (SSN) are assigned sequentially to applicants within geographic areas (which determine the first three digits of the SSN) and a "group" (the middle two digits of the SSN).

${ }^{2}$ The payment was directly deposited only to a personal bank account, a debit card, or a "stored value card" from a personal tax preparer. The payment was mailed for any tax return for which the IRS had the tax preparer's routing number, as for example would occur as part of taking out a 'refund anticipation loan' or paying a tax preparation fee from a refund. These situations represent about a third of the tax refunds (not rebates) delivered via direct deposit in 2007.
} 
Table A.1: The Timing of the Economic Stimulus Payments

\begin{tabular}{cccc}
\hline \hline \multicolumn{2}{c}{ Panel A: Payments by electronic funds } & \multicolumn{2}{c}{ Panel B: Payments by paper check } \\
\hline $\begin{array}{c}\text { Last two digits of } \\
\text { taxpayer SSN }\end{array}$ & $\begin{array}{c}\text { Date funds } \\
\text { transferred to } \\
\text { to account by }\end{array}$ & $\begin{array}{c}\text { Last two digits of } \\
\text { taxpayer SSN }\end{array}$ & $\begin{array}{c}\text { Date check in } \\
\text { the mail by }\end{array}$ \\
\hline $00-20$ & May 2 & $00-09$ & May 16 \\
$21-75$ & May 9 & $10-18$ & May 23 \\
$76-99$ & May 16 & $19-25$ & May 30 \\
& & $26-38$ & June 6 \\
& $39-51$ & June 13 \\
& $52-63$ & June 20 \\
& $64-75$ & June 27 \\
& $76-87$ & July 4 \\
& $88-99$ & July 11 \\
\hline \hline
\end{tabular}

Source: Internal Revenue Service (http://www.irs.gov/newsroom/article/0,id=180247,00.html)

the samples that we analyze because such delays in payment are non-random and so might introduce bias in our inferences based on variation in timing.

\section{A.2 Additional information on the CE data}

Our use of the CE survey follows Parker et al. (2013). We construct the economic stimulus payment variable ESP from the CE 2008 supplemental interview survey data available from the BLS. To create our payments variable, we sum payments for each household in each quarter. Age is the average age of the head and spouse when the household is a married couple, otherwise it is just the age of the head. The number of children is calculated as the number of members of the household younger than 18 .

Nondurable expenditures include expenditures on food (away from home, at home and alcoholic beverages), utilities (and fuels and public services), household operations, public transportation and gas and motor oil, personal care, tobacco, miscellaneous goods, apparel goods and services, health care (excluding payments by employers or insurers), and reading materials. Note that we exclude education which is an investment. Total expenditure adds spending on education, housing (including furniture and appliances and shelter but excluding utilities and household operations, which are already included in nondurable expenditures), transportation (including vehicle purchases, maintenance, and insurance, but excluding public transportation and gas and motor oil), and entertainment (e.g., including TVs and other electronics, as well as fees).

Turning to the sample, we use only data on households that have at least one expenditure interview during the period in which the ESP questions were in the field. We omit observations missing any of the key data that we use in our regressions, such as uncertain stimulus payment status. Our sample omits the bottom one percent of nondurable con- 
sumption expenditures in levels (after adjusting for family size and allowing for a time trend), since this data implies implausibly small (often negative) consumption expenditures. Finally, we drop household observations that report living in student housing, that report age less than 21 or greater than 85, that report age changing by more than one or a negative amount between quarters, or that report changes in the number of children or adults greater than three in absolute magnitude. When we split the sample based on income, we drop households flagged as incompletely reporting income. When we split based on liquid assets, we drop households if the asset information used in computing initial assets (as the difference between final assets and the change in assets) is topcoded.

The CE supplemental survey instruments are in Appendix A.8. The data are available from the BLS.

\section{A.3 Additional information on the Nielsen Consumer Panel}

The Nielsen's Consumer Panel (NCP) is available through the Kilts-Nielsen Data Center at The University of Chicago Booth School of Business. The NCP is a panel survey of U.S. households in 52 metropolitan areas that tracks spending mainly on household goods with Universal Product Codes (UPCs, or "barcodes"). Participants are given barcode scanners to use at the conclusion of every shopping trip for households items to input the total amount spent and then to scan the items they purchase. ${ }^{3}$

Nielsen selects a 'static sample' of actively reporting households in each calendar year and produces sampling weights that are used to make the sample representative of the U.S. population along 10 demographic dimensions (including income). We use data at the weekly level on the trip-level spending on household goods for each household for the year 2008. Participants are surveyed when they begin participating in the survey and at the end of each calendar year about their demographic characteristics and previous year's income, and these answers are used for the following calendar year. We use income for 2007, as reported in the 2009 NCP data files.

The supplemental survey was administered to all households meeting a Nielsen static reporting requirement for January through April 2008, which amounted to 46,620 households by email/web and 13,243 by mail/barcode scanner. For both types of survey, the response rates were $72 \%$ to the first wave, and $80 \%$ after all waves, giving 48,409 survey responses (of which some are invalid). Appendix A.9 contains more information about the survey including information on the multiple waves, the survey instruments, the contact letter and E-mail, and response rates.

The research employs data available from the Kilts Center for Marketing Research at the University of Chicago's Booth School of Business, and a tax rebates survey conducted by Nielsen on behalf of Jonathan Parker and Christian Broda. Despite our best efforts,

\footnotetext{
${ }^{3}$ Participants get newsletters and personalized tips and reminders via email and/or mail to upload spending information and to answer occasional surveys. For regularly uploading information, participants are entered in prize drawings and receive Nielsen points that can be accumulated and used to purchase gifts from a catalogue or prizes.
} 
we have been unable to get Nielsen's cooperation in setting up an archive of the data that would allow researchers to license the data (through Nielsen, the Kilts Center, the Demand Institute, and other places). That said, researchers have been able to license the data directly from Nielsen. See Dhungana and Dogra (2017).

Nielsen has the raw tax rebate survey data, and we are willing to cooperate and do whatever way we can to facilitate the further use of our survey. We originally licensed the data from Ed Grove and Molly Hagen at Nielsen with contract NBT number 11611. Once licensed, we will share programs to read in and merge the different waves of the raw data files and code the survey responses.

The survey was fielded in multiple waves, with each wave following the standard procedures that Nielsen uses to survey the consumer panel households. For households with internet access and who were in communication with Nielsen by email the survey was administered in three waves in a web-based form, and for households without access and in contact with Nielsen by regular mail the survey was administered in only two waves in a paper/barcode scanner form, since the distribution time was slower and the preparation time greater. Repeated surveying was conditional on earlier responses. Households completing the part I of the survey (household characteristics) were in any wave were not asked Part I again. Households reporting payment information in Part II were not re-surveyed. Households that responded to the first question on Part II that they don't know whether they had received a stimulus payment, that they have not received one and "expect to," or respond that they "are unsure whether I will get any" do not proceed to Part II and are re-surveyed with Part II in a later wave (if there is one). Finally, households that respond "No, and I are definitely not getting one" do not proceed and are not re-surveyed.

In terms of timing, the surveys covered the main period during which payments were distributed with random timing. On May 29, 2008, households that had access to the internet were sent by email a request to take the survey with a link, the amount of Nielsen points they would earn by participating, and the deadline by which they must respond. Those who had not responded were sent reminder emails with links on May 30, June 5, and June 11 and the survey wave closed on June 16. Those households not responding and those just receiving Part II of the survey were re-surveyed with an email request on June 26, up to three reminders followed, and the survey closed on July 16. A third wave of the on-line survey ran from July 25 to August 18. Households that did not have access to the internet were first sent surveys by mail on June 18, received up to five reminders conditional on non-response by telephone (roughly every 6 days with the last one on July 17), and the survey closed on July 19. Households were surveyed in a second wave mailed on July 25, received up to five reminders, and the survey closed on September 9, 2008.

We drop all households from the analysis that: i) do not report receiving an payment (roughly 20 percent of the respondents); ii) do not report a date of payment receipt; iii) report not having received a payment in one survey and then later report receiving a payment prior to their response to the earlier in a later survey; iv) report receiving a payment after the date they submitted the survey; v) report receiving a payment by direct deposit (by mail) outside the period of the randomized disbursement by direct deposit 
(mail), and households not reporting means of receipt and reporting receiving a payment outside both periods of randomized disbursement. We allow a two day grace period for reporting relative to survey submit dates, and a seven day grace period for misreporting relative to the period of randomization. We do not adjust the reported date of receipt in either case. We consider weeks in which no expenditures are reported are considered to be weeks with zero expenditures, with the exception that if a household stops reporting expenditure during 2008, we consider spending data from that point on missing rather than zero for these ending weeks of the year.

Further details on the supplemental survey are in Appendix A.9.

\section{A.4 Summary statistics for the CE and the NCP}

Table 1 in the main paper presents summary statistics from our sample for each survey. Relative to previous research, our sample is limited to households that provide both valid payment information and reported preference information. ${ }^{4}$ The NCP spending data is weekly while the CE spending data covers three month periods. Adjusting for frequency, the $\mathrm{CE}$ nondurable spending covers about three times the amount of spending that the NCP data does. Nondurable spending in the CE is about half the total amount spent by households (which adds durable and other expenditures such as home furnishings, tuition, rent and mortgage payments, and auto purchases). The NCP sample has 5 times more households. The NCP sample reports lower average payments. ${ }^{5}$ Two factors contribute to this difference. First, the CE measure of payments is the sum of all payments during a three-month period, while the NCP measure is only the first payment received. Second, the NCP sample, despite similar average family size, has a slightly fewer number of children per household (not shown). The incomes in the two surveys are similar, but the NCP has less cross-sectional dispersion in reported income.

\section{A.5 Additional information on the reported preference ques- tions}

Why do we find a significantly higher share of households reporting that they will mostly spend the payment in the CE than in the NCP? One possibility is that the time lag between payment receipt and the subjective question is greater in the CE than in the NCP. Reported-preference studies of observed spending behavior tend to find that cumulative spending rises over months following the arrival of funds. This is particularly true in studies using credit card data (see Agarwal, Liu and Souleles, 2007), and to a lesser extent for studies using CE data (see Parker et al., 2013). It is also true for reported

\footnotetext{
${ }^{4}$ Our final CE sample thus starts with interviews in September 2007 (when period $t$ in equation (1) below covers expenditures in June to August 2007) and runs through interviews in March 2009 (when period t +1 covers December 2008 to February 2009). Our final NCP sample includes all weeks in 2008.

${ }^{5}$ Parker et al. (2013) and Broda and Parker (2014) document that the reported payments have distributions of amounts, temporal distributions, and patterns across households that are consistent with what is known from other sources and with each other.
} 
spending. Sahm, Shapiro and Slemrod (2010) show that $36 \%$ of those who say that they will mostly spend say their spending rises "within a few weeks," 50\% report "within 1-3 months", and 14\% "more than 3 months" (that paper's Table 3). Thus, since more time has elapsed between payment and survey in the CE, more spending has occurred during this additional time, and so more households report having mostly spent their payments. And existing evidence is qualitatively consistent with this reason for the difference. Sahm, Shapiro and Slemrod (2012) show that the share of households reporting that they will mostly spend rises from 19 percent before the payments are disbursed, to 22 percent a few months afterwards, to 25 percent a year afterwards. Additional evidence is provided in Graziani, van der Klaauw and Zafar (2016) which shows much larger share of households reporting spending after the 2011 payroll tax cut (35 percent) than report that they will spend before it (12 percent). However, that paper attributes the large change in reported behavior to the fact that the policy is a persistent payroll tax cut rather than a one-time payment as studied here.

But there are two reasons to think that the timing of the surveys is not the cause of the difference in reported spending. First, quantitatively, we find a much larger difference - 13 percent over a few weeks - than Sahm, Shapiro and Slemrod (2012) find - 6 percent over more than a year. Second, and we think more important, we considered the issue of time delay in the survey design, and used different wording in each survey. The CE survey asks "Did the tax rebate lead you or someone in your CU [consumer unit] mostly to . . . [emphasis added]" while the NCP instrument asks "Thinking about your household's financial situation this year, is the tax rebate leading you mostly to . . . [emphasis added]." In sum, while it appears that while some of the differences in reported spending may be due to differences in the timing of the questionnaire, the majority of the difference in reported rates is likely due to differences in sample or other differences in the surveys.

\section{A.6 Baseline revealed propensity to spend}

In the $\mathrm{CE}$, we first estimate the following regression equation to measure the average impact of the receipt of a payment on spending:

$$
C_{i, t}-C_{t, t-1}=\alpha(L) P_{i, t}+\boldsymbol{\theta}^{\prime} \mathbf{X}_{i, t}+\tau_{t}+\eta_{i, t}
$$

where $C_{i, t}$ is either the dollar amount of spending or the log of the same, $P_{i, t}$ is the key stimulus payment variable, which is either a dummy variable indicating whether any payment was received by household $i$ in three-month period $t$ or that dummy variable times the amount of the payment received, the $\mathbf{X}_{i, t}$ are change in the number of adults and change in the number of children in the household, included only to reduce unexplained variation in spending, and $\tau_{t}$ is a period-specific intercept. Finally, $\eta_{i, t}$ captures all expenditures unexplained by the previous factors. The parameters of interest are the elements of the lag polynomial $\alpha(L)$ which measure the changes in spending in the period of and periods following receipt relative to the period before the receipt. The polynomial includes all possible lags which is necessary for consistent estimation given possibly long- 
lived spending effects. We present impulse responses in levels by summing the estimates of changes in spending, assuming no spending prior to receipt. ${ }^{6}$

Because it is possible that households with large payments differ from those with small payments, we use an instrumental variables procedure to estimate the causal effect of the payment amount on spending. We instrument the distributed lag of the dollar payment with an indicator of payment receipt. In practice, instrumenting makes little difference to the results.

In the NCP, we have weekly data and do not have access to demographic variables that change during the year so that we estimate monthly (four week) impulse responses in levels directly. To keep the regression models comparable, we include a household-specific intercept, $\mu_{i}$, to capture differences in the average level of spending across households and estimate:

$$
C_{i, t}=\alpha(L) P_{i, t}+\mu_{i}+\tau_{t}+\eta_{i, t}
$$

where $C_{i, t}$ is either the dollar amount of spending or the same divided by average household spending in the first 12 weeks of the year.

Note that consistent identification of the key parameters of interest requires that the variation in $P_{i, t}$ be uncorrelated with all other factors that might influence household expenditure besides the receipt-driven variation of interest. While the timing of payment mailing and payment direct deposit are each effectively random, households are not randomly assigned to different methods of disbursement. However, we find quite small differences in average spending responses between households receiving stimulus payments by mail and by direct deposit. And so, in the interests of statistical power (and lacking evidence to the contrary), we treat all variation in timing as valid for identifying heterogeneity in the spending response.

Tables A.2 and A.3 report estimates of the average spending responses in the CE and NCP data respectively. Each table displays result for three different combinations of spending measure $\left(C_{i, t}\right)$ and payment measure $\left(P_{i, t}\right)$. In the first column, spending in dollars is regressed on an indicator variable for payment receipt so that the estimated coefficients measure the dollar increase in spending on payment arrival and in the periods following. Panels A and B show that in the CE we find significant and persistently high spending concurrent and following receipt. The average spending response of nondurable goods is $\$ 298$ (highly statistically significant) in the three-month period of receipt and $\$ 269$ (statistically insignificant) over the next three months. The cumulative amount, $\$ 567$, has a standard error of $\$ 280$. Panel B shows larger dollar spending on CE total expenditures with similar levels of statistical significance.

The first column of Table A.3 shows that in the NCP we find a spending response on the smaller subset of goods measure in the NCP of $\$ 40$ (highly statistically significant) in the month of and following receipt, and $\$ 6-7$ (statistically insignificant) in each of the

\footnotetext{
${ }^{6}$ We also find similar but weaker results if we allow for some anticipatory spending by including one lead of $P$ in the lag polynial (ie. the lead picks up very little spending in anticipation of receipt). We find similar spending short run spending effects if we instead estimate in levels.
} 
Table A.2: Revealed Spending Response to Receipt of Stimulus Payment, CE

\begin{tabular}{|c|c|c|c|}
\hline $\begin{array}{l}\text { Specification: } \\
\text { (Interpretation) }\end{array}$ & $\begin{array}{l}\text { Spending on } \\
\text { Indicator } \\
\text { (Increase } \\
\text { in dollars) } \\
\end{array}$ & $\begin{array}{c}\text { Log Spending } \\
\text { on Indicator } \\
\text { (Avg. pct. increase } \\
\text { in spending) }\end{array}$ & $\begin{array}{c}\text { \$ Spending on } \\
\text { Amount, 2SLS } \\
\text { (Increase as pct. } \\
\text { of payment) }\end{array}$ \\
\hline \multicolumn{4}{|c|}{ Panel A: CE Spending on Non-Durable Goods } \\
\hline $\begin{array}{l}\text { Three Month Period } \\
\text { of Receipt }\end{array}$ & $\begin{array}{l}298 \\
(106)\end{array}$ & $\begin{array}{c}4.72 \\
(1.65)\end{array}$ & $\begin{array}{c}31.1 \\
(11.9)\end{array}$ \\
\hline $\begin{array}{l}\text { First Three Month Period } \\
\text { After Period of Receipt }\end{array}$ & $\begin{array}{c}269 \\
(189)\end{array}$ & $\begin{array}{c}4.79 \\
(2.93)\end{array}$ & $\begin{array}{c}26.5 \\
(22.4)\end{array}$ \\
\hline $\begin{array}{l}\text { Second Three-Month Period } \\
\text { After Period of Receipt }\end{array}$ & $\begin{array}{l}172 \\
(267)\end{array}$ & $\begin{array}{c}3.73 \\
(4.24)\end{array}$ & $\begin{array}{l}15.8 \\
(31.5)\end{array}$ \\
\hline $\begin{array}{c}\text { Effect over Period of } \\
\text { Receipt \& Period After }\end{array}$ & $\begin{array}{c}567 \\
(280) \\
\end{array}$ & $\begin{array}{c}4.76 \\
(2.19) \\
\end{array}$ & $\begin{array}{c}57.6 \\
(32.9) \\
\end{array}$ \\
\hline \multicolumn{4}{|c|}{ Panel B: CE Total Spending } \\
\hline $\begin{array}{c}\text { Three Month Period } \\
\text { of Receipt }\end{array}$ & $\begin{array}{c}730 \\
(340)\end{array}$ & $\begin{array}{c}4.25 \\
(2.11)\end{array}$ & $\begin{array}{c}74.1 \\
(38.6)\end{array}$ \\
\hline $\begin{array}{l}\text { First Three Month Period } \\
\text { After Period of Receipt }\end{array}$ & $\begin{array}{c}473 \\
(588)\end{array}$ & $\begin{array}{c}0.64 \\
(3.79)\end{array}$ & $\begin{array}{c}41.6 \\
(69.9)\end{array}$ \\
\hline $\begin{array}{l}\text { Second Three-Month Period } \\
\text { After Period of Receipt }\end{array}$ & $\begin{array}{c}170 \\
(870)\end{array}$ & $\begin{array}{l}-2.60 \\
(5.53)\end{array}$ & $\begin{array}{c}8.1 \\
(103.0)\end{array}$ \\
\hline $\begin{array}{c}\text { Effect over Period of } \\
\text { Receipt \& Period After }\end{array}$ & $\begin{array}{l}1,204 \\
(891) \\
\end{array}$ & $\begin{array}{c}2.45 \\
(2.83) \\
\end{array}$ & $\begin{array}{c}115.7 \\
(105.0) \\
\end{array}$ \\
\hline
\end{tabular}

Note: This table reports results from regressions of the change in household spending (or the log-change) on a distributed lag of an indicator of payment receipt, or the amount instrumented with this indicator, as well as period fixed effects, age, change in the number of children and change in the number of adults. Data covers 10,353 observations on 4,296 households. CE weights are used. Parentheses contain standard errors that are robust to arbitrary heteroskedasticity and within-household correlation. 
Table A.3: Revealed Spending Response to Receipt of Stimulus Payment, NCP

\begin{tabular}{cccc}
\hline \hline Specification: & $\begin{array}{c}\text { \$ Spending on } \\
\text { Indicator } \\
\text { (Interpretation) } \\
\text { dollars) }\end{array}$ & $\begin{array}{c}\text { Spending as Pct. of } \\
\text { Avg. Q1 on Indicator } \\
\text { (Avg. pct. increase } \\
\text { in spending) }\end{array}$ & $\begin{array}{c}\text { \$ Spending on } \\
\text { Amount, 2SLS } \\
\text { (nncrease as pct. } \\
\text { of payment) }\end{array}$ \\
\hline Month Following & 39.94 & 6.89 & 4.31 \\
Receipt & $(5.61)$ & $(1.26)$ & $(0.62)$ \\
Second Month & 6.95 & 1.80 & 0.50 \\
Following Receipt & $(7.01)$ & $(1.60)$ & $(0.70)$ \\
Third Month & 6.08 & 2.00 & 0.30 \\
Following Receipt & $(9.35)$ & $(2.00)$ & $(1.00)$ \\
\hline Effect over First & 52.97 & 3.57 & 5.06 \\
Three Months & $(19.57)$ & $(1.50)$ & $(2.02)$ \\
\hline \hline
\end{tabular}

Note: Each column reports results from a regressions of dollar spending or that normalized by average monthly spending during 2008Q1 on a complete distributed lag of an indicator of payment receipt or the indicator used as an instrument for the amount, as well as month and household effects. Parentheses contain standard errors that are robust to arbitrary heteroskedasticity and within-household correlation. Calculations are based on data from The Nielsen Company (US) LLC and provided by the Marketing Data Center at the University of Chicago Booth School of Business.

following months. Comparing the measures in the two datasets, nondurable spending measured in the CE is 2.8 times larger than that in the NCP and the spending response is larger by roughly a factor of 6 , so that the spending response appears to be lower in the NCP than in the CE. ${ }^{7}$

The second columns of Tables A.2 and A.3 measure the average percent increase in spending upon arrival and shortly following. ${ }^{8}$ In percent terms, the estimated responses are quite similar across datasets. Spending rises by $3.8 \%$ in the three months in which the payment arrives in the CE, which is quite comparable to the average of the increases of $6.9 \%$ and $1.8 \%$ that we find in the first two months in the NCP, and with the average increase of $3.6 \%$ over the first three months (last row).

\footnotetext{
${ }^{7}$ This difference is mitigated by the fact that a larger share of spending in the NCP is on categories of goods like food at home that are less responsive to tax rebates.

${ }^{8}$ In the CE data, we use the dependent variable change in log spending, while in the NCP we use spending divided by average weekly spending in the first quarter of 2008.
} 
The third columns of Tables A.2 and A.3 report the propensity to spend or percent of the payment spent, which is our main specification for the rest of the paper. We use the dollar amount of any payment as the key endogenous regressor, and an indicator of payment receipt in place of this amount in the instrument set. Inference accounts for the two-step estimation procedure (and still clustered by household).

Table A.2, Panel A shows that households spent 31\% of their payments on nondurable goods in the three month period of arrival; Panel B shows $74 \%$ spent on all CE-measured consumption goods and services. Both measures show some continued but impreciselymeasured spending. In the NCP, Table A.3 shows that we find 4.3 percent of the payment spent in the month of and following receipt on goods measured in the NCP. ${ }^{9}$ Given average payments amounts, these propensities to consume are consistent with the dollar spending in the first columns of both Tables, so that we again estimate a slightly lower rate of spending in the NCP than in the CE after adjusting for less spending measured in the NCP. ${ }^{10}$ Although this difference between surveys is not statistically strong, it is consistent with the difference in reported propensities presented in Table 3 where we show that 17 percent of the NCP sample reports mostly spending their payments as compared to 32 percent in the CE.

In the $\mathrm{CE}$, the revealed propensity to spend is $31 \%$ on nondurable goods during the three months of arrival and about a third of households report mostly spending their payments, which implies the two methods are broadly consistent with each other, as interpreted in the early literature (e.g. Shapiro and Slemrod, 2003a). But this is a weak standard. Further, the estimate of spending in the CE that includes durable goods is substantially larger, and the estimates of spending in the NCP that include only household items are also not readily comparable.

Finally, we make one note about the timing of spending and the comparability of reported-preference and revealed-preference measures of spending. Table A.3 shows that the additional spending caused by the arrival of a payment declines after the payment, so that there appears to be little additional spending after the first period or two. ${ }^{11}$

\section{A.7 Further discussion and details of results}

Any indirect or general equilibrium channels through which the payments program affected spending - such as through changes in output, wages, and future taxes - are likely

\footnotetext{
${ }^{9}$ In comparison, Parker et al. (2013) finds that the arrival of a payment caused an increase in total spending amount of $78 \%$ (Table 4, Panel C) or $91 \%$ (Table 3, Panel C) of the payments, whereas we find only $74 \%$ in this sample.

${ }^{10}$ To be more quantitative, and ignoring possible differences due to differing spending propensities across goods, the revealed propensity to spend in the NCP would be about 14 percent if measured spending were scaled up by 2.8 times to CE nondurable goods larger. Scaling by 9.4 to total CE spending would instead give a propensity of 47 percent. The corresponding numbers in the CE are 31 and 74 percent.

${ }^{11}$ This is not the case for other datasets and methodologies and samples. The subset of households with credit cards that are near to their credit limits first pay off credit card debt, and then spend at steadily higher rates over a 9 month period until their credit card utilization returns to where it was initially (Agarwal, Liu and Souleles, 2007).
} 
omitted from both reported-preference and revealed-preference measures and so pose no problems for our comparison of methodologies. Shapiro and Slemrod $(2003 a, 2003 b)$ find evidence consistent with this conclusion. The percent of households that report that they mostly spent the 2001 tax rebate was not economically or statistically significantly different between: i) households who thought the 2001 tax cut would make their personal finances better off and those who thought it would make them worse off; ii) those who thought the tax cut would improve the economy and those who thought it would worsen it; and iii) those who thought the tax cuts would increase government spending and those who thought it would decrease it.

In Table 3, Panels $\mathrm{A}$ and $\mathrm{B}$, there are similar higher levels of continued spending estimated in the subsequent three month period, although none of these differences are statistically significant.

There is some statistically weak evidence that households that report saving spend later in time than those that report paying down debt. Households reporting mostly saving had a slightly lower propensity to spend immediately on receipt (Panels A and C in Table 3) and a slightly higher propensity to spend later or on durable goods (Panels $\mathrm{B}$ and $\mathrm{D})$, relative to those reporting that they used their payments mostly to pay down debt.

To construct the propensities to spend estimated by revealed and reported preference methods for the NCP in Table 4, we scale the estimated propensities in the NCP to total spending in two ways, one revealed and one reported. The scale factor derived from revealed spending is the ratio of the estimated propensity to spend on NCP-type goods in the CE to the propensity to spend on all categories of spending (9.4). The scale factor derived from reported-spending is the ratio of reported propensity to spend on NCP goods to the propensity to spend on all categories of spending from the NCP supplemental survey.

To calibrate the average propensity to spend following Sahm, Shapiro and Slemrod, 2010, we derive a household-level distribution of propensities to consume based on the share of households reporting 'mostly spend' and the following Sahm, Shapiro and Slemrod, 2010 assumptions: that a report of 'mostly spend' corresponds to a propensity to spend of one-half or greater, and that the density of the propensity to spend in the population is piecewise linear. Specifically the density consists of two lines with a kink at the share of households reporting mostly spending, a height of $A$ at zero propensity, and a maximum propensity to spend of $\chi$. Given that the density must integrate to one, the density is unique given a share of mostly spend and $\chi$.

Our second calibration instead assumes $\chi=1.2-$ consistent with some households purchasing durable goods and spending more than the payment amount. We also assume that the density is not continuous, but instead, the propensity to spend of households reporting that they did not mostly spend is uniformly distributed. We make this second assumption because without it the population average propensity to spend is decreasing in the assumed maximal propensity to spend. Further, without this second assumption, given our shares reporting 'mostly spend,' the distribution of propensities has a mode at the origin rather than at the share of households reporting 'mostly spend' (as intended 
by Shapiro and Slemrod, 2003b).

We reanalyzed Jappelli and Pistaferri (2014)'s data and find that households with more financial assets alone also have higher propensities to spend, so that their finding is not simply driven by income in their measure of cash on hand. But we also find that there is no relationship in the SHIW between reported spending propensities and financial assets less debt. Could different measures of assets and liquidity be causing the difference between findings? It is possible that our data would show a difference in reported spending with a different measure of assets, or that the SHIW would for a measure of liquidity. However, it seems more likely that one of the remaining differences is the culprit. 


\section{A.8: The CE 2008 ESP Survey Instrument}

The following questions were asked in all CE interviews in June 2008 - March 2009.

First questions about rebate amount, date and means of receipt.

[Earlier this year/Last year] the Federal government approved an economic stimulus package.

[Many households will receive a one-time economic stimulus payment, either by check or direct deposit/Previously you or your CU [[consumer unit]] reported receiving one or more economic stimulus payments.] This is also called a tax rebate and is different from a refund on your annual income taxes.

Since the first of the reference month, have you or any members of your CU received a/an additional

10. Tax rebate? [Economic Stimulus Payment]

99. None/No more entries

Who was the rebate for? [enter text]

* Collect each rebate separately and include the name(s) of the recipient(s).

In what month did you receive the rebate? [enter text]

What was the total amount of the rebate? [enter value]

* Probe if the amount is not an expected increment such as $\$ 300, \$ 600, \$ 900, \$ 1,200$, etc

Was the rebate received by - ?

1 . check?

2. direct deposit?

Did you or any members of your CU receive any other tax rebate [economic stimulus payment]? $\underline{1 .}$ Yes

2. No

If yes, return to "Who was the tax rebate for?"

Earlier, you or someone in your CU [consumer unit] reported receiving a one-time tax rebate that was part of the Federal government's economic stimulus package.

Did the tax rebate lead you or someone in your CU [consumer unit] mostly to increase spending, mostly to increase savings, or mostly to pay off debt?

1. Mostly to increase spending

2. Mostly to increase savings

3. Mostly to pay off debt 


\section{Appendix A.9: NCP survey timing, invitations, reminders, and instruments}

\section{Timing of surveys and reminders}

\begin{tabular}{|c|c|c|c|}
\hline \# & Task & Start & Finish \\
\hline & Online Tax Rebate Survey \#280556 - Wave 1 & & \\
\hline & Production launch Wave 1 online survey & & \\
\hline 10 & Production launch of online Tax Rebate Full Survey & $05 / 27 / 08$ & $05 / 27 / 08$ \\
\hline 11 & Email reminder \#1 & $05 / 30 / 08$ & $05 / 30 / 08$ \\
\hline 12 & Email reminder \#2 & $06 / 05 / 08$ & $06 / 05 / 08$ \\
\hline 13 & Email reminder \#3 & $06 / 11 / 08$ & $06 / 11 / 08$ \\
\hline \multirow[t]{3}{*}{14} & Close online survey & $06 / 16 / 08$ & $06 / 16 / 08$ \\
\hline & Online Tax Rebate Survey \#280556 - Wave 2 & & \\
\hline & $\begin{array}{l}\text { Production launch Wave } 2 \text { non respd full online survey } \\
\text { Production launch Wave } 2 \text { Part } 2 \text { survey }\end{array}$ & & \\
\hline 19 & Production launch of Wave 2 Non responders survey & $06 / 26 / 08$ & $06 / 26 / 08$ \\
\hline 20 & Email reminder \#1 & $07 / 02 / 08$ & $07 / 02 / 08$ \\
\hline 21 & Email reminder \#2 & $07 / 08 / 08$ & $07 / 08 / 08$ \\
\hline 22 & Email reminder \#3 & $07 / 11 / 08$ & $07 / 11 / 08$ \\
\hline \multirow[t]{3}{*}{23} & Close online survey & $07 / 16 / 08$ & $07 / 16 / 08$ \\
\hline & Online Tax Rebate Survey \#280556 - Wave 3 & & \\
\hline & $\begin{array}{l}\text { Production launch Wave } 3 \text { non respd full online survey } \\
\text { Production launch of Wave } 3 \text { Part } 2 \text { survey }\end{array}$ & & \\
\hline 33 & Production launch of Wave 3 Non responders survey & $07 / 25 / 08$ & $07 / 25 / 08$ \\
\hline 34 & Email reminder \#1 & $07 / 30 / 08$ & $07 / 30 / 08$ \\
\hline 35 & Email reminder \#2 & $08 / 06 / 08$ & $08 / 06 / 08$ \\
\hline 36 & Email reminder \#3 & $08 / 13 / 08$ & $08 / 13 / 08$ \\
\hline 37 & Close online survey & $08 / 18 / 08$ & $08 / 18 / 08$ \\
\hline
\end{tabular}

\begin{tabular}{|l|l|l|l|}
\hline & Paper Tax Rebate Survey \#280532 - Wave 1 & & \\
\hline & Programming of paper survey & & \\
\hline $\mathbf{4 8}$ & Production paper mailing date & $06 / 13 / 08$ & $06 / 13 / 08$ \\
\hline $\mathbf{4 9}$ & Telecom reminders & $06 / 19 / 08$ & $06 / 19 / 08$ \\
\hline $\mathbf{5 0}$ & Telecom reminders & $06 / 26 / 08$ & $06 / 26 / 08$ \\
\hline $\mathbf{5 1}$ & Telecom reminders & $07 / 03 / 08$ & $07 / 03 / 08$ \\
\hline $\mathbf{5 2}$ & Telecom reminders & $07 / 10 / 08$ & $07 / 10 / 08$ \\
\hline $\mathbf{5 3}$ & Telecom reminders & $07 / 17 / 08$ & $07 / 17 / 08$ \\
\hline $\mathbf{5 4}$ & Close paper survey Wave 1 & $07 / 19 / 08$ & $07 / 19 / 08$ \\
\hline & & & \\
\hline & Paper Tax Rebate Survey \#280532 - Wave 2 & & \\
\hline & Production launch of Wave 2 paper surveys & & \\
\hline $\mathbf{6 0}$ & Production paper mailing date & $07 / 25 / 08$ & $07 / 25 / 08$ \\
\hline $\mathbf{6 1}$ & Telecom reminders (estimate) & $07 / 31 / 08$ & $07 / 31 / 08$ \\
\hline $\mathbf{6 2}$ & Telecom reminders (estimate) & $08 / 07 / 08$ & $08 / 07 / 08$ \\
\hline $\mathbf{6 3}$ & Telecom reminders (estimate) & $08 / 14 / 08$ & $08 / 14 / 08$ \\
\hline $\mathbf{6 4}$ & Telecom reminders (estimate) & $08 / 21 / 08$ & $08 / 21 / 08$ \\
\hline $\mathbf{6 5}$ & Telecom reminders (estimate) & $08 / 28 / 08$ & $08 / 28 / 08$ \\
\hline $\mathbf{6 6}$ & Close paper surveys Wave 2 & $09 / 06 / 08$ & $09 / 06 / 08$ \\
\hline & & & \\
\hline
\end{tabular}




\section{Cover page and email request to participate and reminders}

The cover of the mailed paper survey was written in the standard format in which Nielsen communicated with its panelists that do not fill out surveys on line. The email request to fill out the survey on line was similarly written in the standard format in which Nielsen communicated with its panelists who respond on line. The specific text, in the cover page or email, stated that "We could all use some extra money, and, earlier this year, the Federal government approved a one-time economic stimulus payment also referred to as a tax rebate, for some households. A special survey is enclosed regarding this rebate." Following this instruction were specific (and standard) instructions regarding how to complete the survey. In particular the survey was to be completed by "the adult household member most knowledgeable about your household's income and tax returns," underlined on the cover page and in bold in the email. Each communication also described the number of bonus gift points that would be earned by participating in the survey.

Reminders send to households by email or communicated to households by phone similarly emphasized the topic of the survey, that it should be completed by the person most familiar with the household's income and taxes, the brevity of the survey (it was estimated to take about ten minutes), and the points that completion would earn. Reminders also offered assistance through the on-line support center or by phone for any panelists encountering difficulties. 
Web version for households with on-line capabilities

\section{Tax Rebate Survey}

This survey should be completed by the adult household member most knowledgeable about your household's income tax returns.

- Part One asks several questions related to general household financial planning.

- Part Two asks several questions relating to a federal government economic stimulus program, commonly referred to as the Tax Rebate program.

Before answering the survey, please read the following instructions to ensure that we receive your important responses:

- Maximize your computer screen for the best view of the survey.

- Always click the NEXT button at the bottom of each page after answering the question(s) on that page.

- Click the SUBMIT SURVEY button after you finish the survey. Please DO NOT click on the CLOSE button until after you have submitted the survey or we may not receive your responses correctly.

Thank you very much for your cooperation and participation in our online surveys! 


\section{Part One}

Before going on a vacation, how much time do you spend examining where you would most like to go and what you would like to do?

D A great deal of time

Q Quite a bit of time

(a A little time

D Almost no time

Do not go on vacation

Many people sometimes buy things that they later wish they had not bought. About how often do you or other household members make purchases that you later regret?

D Often

D Occasionally

Q Rarely

D Never

In general, are you or other household members the sort of people who would rather spend your money and enjoy it today or save more for the future?

D Spend now

a Save for the future

Next

In case of an unexpected decline in income or increase in expenses, do you have at least two months of income available in cash, bank accounts, or easily accessible funds?

(a) Yes

0 No

Next 
In the last few years, have you gathered together your household's financial information, reviewed it in detail, and formulated a financial plan for your household's long term future?

(a) Yes

No

Next

\section{Part Two}

Earlier this year the Federal government approved an economic stimulus package. This year many households will receive a one-time economic stimulus payment, commonly called a tax rebate, either by check or direct deposit. This is different from a refund on your annual income taxes.

Next

Has your household received a tax rebate (stimulus payment) this year?

[ Yes

D No, but we are expecting to

D No, and we are unsure whether we will get any

D No, and we are definitely not getting one

D Not sure/don't know

Next

In what month did you receive this tax rebate (please respond for the larger rebate if your household received more than one)?

D April

Q May

D June

D July

Next

As closely as you can recall, on what day of the month did you receive the rebate?

(Click here to choose) 
Was this rebate received by direct deposit or check?

D Direct deposit to checking or savings account

D Check by US mail

D Don't know

Next

What was the dollar amount of this tax rebate (stimulus payment)?

$\$$

Next

Was this about the amount you were expecting?

D No, and we were surprised to get any rebate at all

D No, and it was less than we were expecting

D No, and it was more than we were expecting

D Yes, and we've known the approximate amount since February

D Yes, and we've known the approximate amount since March

D Yes, and we've known the approximate amount since April

Q Yes, but we only learned about it recently Next

Thinking about your household's financial situation this year, is the tax rebate leading you mostly to increase spending, mostly to increase savings, or mostly to pay off debt? 


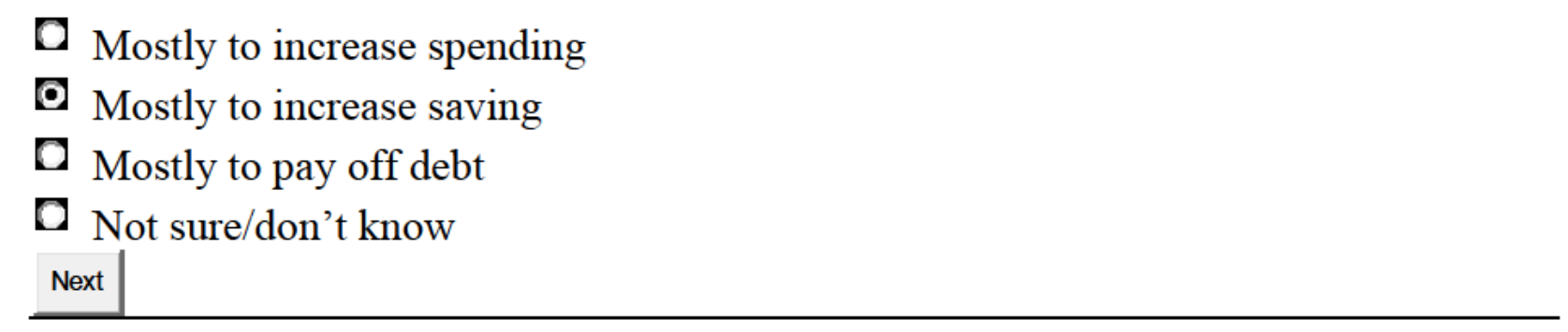

For the following questions, please think about the extra amount you are spending because of this rebate. How much (in dollars rounded to the nearest dollar) are you spending on each of the following:

Dollar Amount

Food, health \& beauty aids, and household products

Entertainment or personal services, such as restaurants, vacations, and movie tickets

Durable goods such as appliances, electronics and furniture

Clothing, shoes or accessories

All other types of purchases

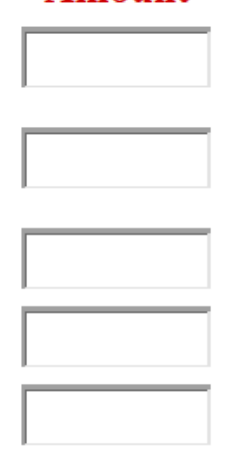


Response rates by survey and wave

Online

\begin{tabular}{|c|c|c|c|c|c|c|c|}
\hline & $\begin{array}{c}\text { actual } \\
\text { outgoing }\end{array}$ & responded & $\begin{array}{c}\text { part } 2 \text { - } \\
\text { Q6=1 yes }\end{array}$ & $\begin{array}{c}\text { part } 2 \text { - } \\
Q 6=2,3,5\end{array}$ & $\begin{array}{l}\text { part } 2-Q 6=4 \\
\text { definitely not }\end{array}$ & $\begin{array}{l}\text { non- } \\
\text { respondents }\end{array}$ & $\begin{array}{c}\text { response } \\
\text { rate }\end{array}$ \\
\hline wave 1 (part 1 and 2) - 280556 & 46620 & 33910 & 17974 & 13831 & 2105 & 12710 & 72.7 \\
\hline wave 2 (part 2 only) -280560 & 13407 & 11158 & 5842 & 4883 & 433 & 2249 & 83.2 \\
\hline wave 2 (part 1 and 2) - 280683 & 9480 & 2230 & 1689 & 372 & 168 & 7250 & 23.5 \\
\hline wave 3 (part 2 only) -280757 & 7081 & 5631 & 3957 & 1343 & 331 & 1450 & 79.5 \\
\hline wave 3 (part 1 and 2) - 280756 & 6005 & 1133 & 945 & 108 & 80 & 4872 & 18.9 \\
\hline Overall & & 37273 & & & & & 80.0 \\
\hline \multicolumn{8}{|l|}{ Paper } \\
\hline wave 1 (part 1 and 2) - 280532 & 13243 & 9541 & 5544 & 3416 & 581 & 3702 & 72.0 \\
\hline wave 2 (part 2 only) -280534 & 3408 & 2783 & 2073 & 566 & 144 & 625 & 81.7 \\
\hline wave 2 (part 1 and 2) - 280599 & 3166 & 1634 & 1259 & 251 & 124 & 1532 & 51.6 \\
\hline Overall & & 11175 & & & & & 84.4 \\
\hline total respondent count & 59863 & 48448 & & & & & 80.9 \\
\hline
\end{tabular}




\section{Appendix A.10: A notification letter for an ESP by electric funds transfer}

Department of the Treasury

Internal Revenue Service

Andover, MA 05501-0025

\author{
Notice Date: May 12, 2008 \\ Notice Number: CP 1378
}

Taxpayer Identification Number:

Primary: XXX-XX-

For assistance, you may call:

$1-866-234-2942$

\section{Understanding Your Economic Stimulus Payment}

\section{Please keep a copy of this notice for your records.}

Dear Taxpayer:

\section{Your Economic Stimulus Payment}

You are entitled to an economic stimulus payment of $\$ 600.00$ as provided by the Economic Stimulus Act of 2008 . You can expect your payment by $5 / 9 / 08$. If you do not receive it within six weeks of this notice, please contact us at the number shown above. You will not be required to report the amount of your stimulus payment as taxable income on your 2008 federal income tax return. If you receive any federal benefits or federally financed benefits, those benefits generally will not be affected by any stimulus payment you receive.

\section{What You Need To Do}

You do not need to do anything. If you received a refund on your 2007 federal income tax return and had it directly deposited into a bank account, we will directly deposit your stimulus payment into the same bank account. If not, your stimulus payment check will be mailed to you. If your tax refund was directly deposited into a refund anticipation loan account, your stimulus payment check will be mailed to you.

\section{How We Calculated Your Payment}

Your payment is based on information you submitted on your 2007 federal income tax return such as your filing status, the number of qualifying children, and your net income tax liability. The next page shows a detailed explanation of how we calculated your stimulus payment.

Note: You will not be required to report the amount of your stimulus payment as taxable income on your 2008 federal income tax return.

For general information, tax forms, and publications or to view "Where is My Stimulus Payment", visit www.irs.gov 


\begin{tabular}{|l|lr|}
\hline \multicolumn{3}{|c|}{ Your Stimulus Payment Calculation } \\
\hline + Filing Status & $\$$ & 600.00 \\
\hline + For qualifying children & $\$$ & 0.00 \\
\hline - Reduction for Adjusted Gross Income Limitation & $\$$ & 0.00 \\
\hline = Your Calculated Stimulus Payment & $\$$ & 600.00 \\
\hline
\end{tabular}

Details of Your Stimulus Payment Calculation

We calculated your stimulus payment based on the following rules.

\section{Filing Status}

Based on your filing status, the amount of your stimulus payment is $\$ 600$ or your 2007 net income tax liability, whichever is less. Net income tax liability is your tax before credits, including the alternative minimum tax, less all non-refundable credits other than the allowable child tax credit.

However, if the net income tax liability on your 2007 federal income tax return is less than $\$ 300$ and you had $\$ 3,000$ or more in qualifying income, the amount of your stimulus payment is $\$ 300$. "Qualifying Income" refers to wages, net eamings from self-employment that is includible in taxable income, Social Security benefits, certain tier 1 Railroad Retirement benefits, certain disability compensation, disability pension or survivors' benefits received from the Department of Veterans Affairs, and nontaxable combat pay (if it was listed on your tax return).

\section{Qualifying Children}

The calculation is based on the number of qualifying children multiplied by $\$ 300$. A child is generally considered a qualifying child for the calculation of your 2008 stimulus payment if the child was born after December 31,1990, and has a valid Social Security Number. The number of qualifying children shown on your 2007 federal income tax return was 0.

\section{Whom You Can Contact With Questions}

If you need additional information, please visit the IRS website at www.irs.gov or call 1-866-234-2942. 1F220539281-2AN-3AN-5-17-18N-19N-7N-OTN-OFN 


\section{References}

Agarwal, Sumit, Chunlin Liu, and Nicholas S. Souleles. 2007. "The Response of Consumer Spending and Debt to Tax Rebates - Evidence from Consumer Credit Data." Journal of Political Economy, 115(6): 986-1019.

Broda, Christian, and Jonathan A. Parker. 2014. "The Economic Stimulus Payments of 2008 and the Aggregate Demand for Consumption." Journal of Monetary Economics, 68(S20-36).

Dhungana, Sandesh, and Keshav Dogra. 2017. "Regional Heterogeneity in Fiscal Stimulus Effectiveness: The Economic Stimulus Payments of 2008." Manuscript, Columbia and Federal Reserve Bank of New York.

Graziani, Grant, Wilbert van der Klaauw, and Basit Zafar. 2016. "Workers' Spending Response to the 2011 Payroll Tax Cuts." American Economic Journal: Economic Policy, 8(4): 124-59.

Internal Revenue Service U. S. Department of the Treasury. 2008. "IRS Announces Economic Stimulus Payment Schedules, Provides Online Payment Calculator." https://www.irs.gov/uac/irs-announces-economic-stimulus-payment-schedulesprovides-online-payment-calculator.

Jappelli, Tullio, and Luigi Pistaferri. 2014. "Fiscal Policy and MPC Heterogeneity." American Economic Journal: Macroeconomics, 6(4): 107-36.

Parker, Jonathan A., Nicholas S. Souleles, David S. Johnson, and Robert McClelland. 2013. "Consumer Spending and the Economic Stimulus Payments of 2008." American Economic Review, 103(6): 2530-53.

Sahm, Claudia R., Matthew D. Shapiro, and Joel Slemrod. 2010. "Household Response to the 2008 Tax Rebate: Survey Evidence and Aggregate Implications." In Tax Policy and the Economy, Volume 24. NBER Chapters, 69-110. National Bureau of Economic Research, Inc.

Sahm, Claudia R., Matthew D. Shapiro, and Joel Slemrod. 2012. "Check in the Mail or More in the Paycheck: Does the Effectiveness of Fiscal Stimulus Depend on How It Is Delivered?" American Economic Journal: Economic Policy, 4(3): 216-50.

Shapiro, Matthew D., and Joel Slemrod. 2003a. "Consumer Response to Tax Rebates." American Economic Review, 93(1): 381-396.

Shapiro, Matthew D., and Joel Slemrod. 2003b. "Did the 2001 Tax Rebate Stimulate Spending? Evidence from Taxpayer Surveys." Tax Policy and the Economy, 17: 83-109. 